\title{
Effects of dimethylsulfoxide and pentoxifylline in the vitality of cutaneous flaps in rats
}

\section{Efeitos do dimetilsulfóxido e da pentoxifilina na vitalidade de retalhos cutâneos em ratos}

Stephanie luzia da Costa Pedretti'; Cicero de lima Rena, eCbC-Mg²; Maria Christina Marques nogueira Castãnon²; Ana Paula do Nascimento Duquez'; Fernando Henrique Pereira'; Tarcizo Afonso Nunes¹.

\section{A B S T R A C T}

\begin{abstract}
Objectives: to verify the influence of dimethylsulfoxide and pentoxifylline on the vitality of cutaneous flaps in rats and the tissue repair process. Methods: were studied 30 Wistar rats, submitting them to a $2 \mathrm{~cm}$ wide by $8 \mathrm{~cm}$ long dorsal cutaneous flap, of caudal base. We distributed the animals in three groups: Control Group ( $n=10)$ with application gauze moistened with $0.9 \%$ Saline in the flap bed for 30 seconds; Dimethylsulfoxide group ( $n=10$ ), with administration of $1 \mathrm{ml}$ of $5 \%$ dimethylsulfoxide divided into five injections of $0.2 \mathrm{ml}$ in the transition of the flap segments; Pentoxifylline group ( $n=10)$, with administration of pentoxifylline $20 \mathrm{mg} / \mathrm{kg}$, diluted to $1 \mathrm{ml}$ and divided into five injections of $0.2 \mathrm{ml}$ in the transition of the flap segments. Drugs were administered intraoperatively, in a single dose and subcutaneously. We observed the skin flaps for changes in color and texture. On the 10th postoperative day, we checked the dimensions of viable and necrotic tissues, followed by excision of the specimen for histological analysis. Results: the measurements of length of the viable and necrotic tissues between groups showed no differences. Histological analysis showed that the Dimethylsulfoxide group presented neovascularization, inflammatory infiltrate with leukocytes and more structured conjunctival stroma. The Pentoxifylline group showed neovascularization and inflammatory infiltrate, with moderate to intense granulation. The control group evolved with a higher rate of necrosis in the distal segment. Conclusion: dimethylsulfoxide and pentoxifylline influenced the vitality of the flap and the tissue repair process. However, they did not prevent necrosis macroscopically.
\end{abstract}

Keywords: Wound Healing. Dimethyl Sulfoxide. Pentoxifylline. Rats. Surgical flaps.

\section{INTRODUCTION}

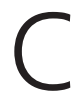
utaneous flaps are one of the pillars of reconstructions in the specialty of Plastic Surgery. A surgical resource widely used in situations of tissue loss of the integumentary system due to trauma, tumor resection and ischemia, it can present several complications, among them, hematoma, infection, dehiscence and necrosis. The cutaneous flap consists of elevation, detachment and repositioning in the bed, a procedure that can induce a series of events, among which vascular deficit, with reduced perfusion, for a variable and transient period ${ }^{1}$. In addition to partial interruption of blood flow, the venous return in the dermal and subdermal plexus is impaired. Venous occlusion or congestion can be damaging to the vitality of the flap. Lym- phatic vessels are also injured, resulting in interstitial edema, contributing to the reduction of capillary perfusion. The sensory and sympathetic nerves are injured with the flap elevation, which causes the release of catecholamines, inducing vasoconstriction and reduction of the local blood supply. It is important to note that the skin flap has to survive the events that occur during the period of reduced perfusion".

The ischemia of the cutaneous flap on the more distal area of vascular supply, especially in the distal segment, even if fleeting and for a short period, can generate reactive oxygen species. The mechanism involved in reperfusion, with the restoration of vascular supply and oxygen influx in the ischemic tissue, can culminate in cellular, inflammatory and metabolic changes mediated by free radicals, with structural and

1 - Federal University of Minas Gerais, Belo Horizonte, MG, Brazil. 2 - Federal University of Juiz de Fora, Juiz de Fora, MG, Brazil. 
functional modifications in the cell, which may contribute to tissue necrosis ${ }^{2-7}$. This event requires organic adaptations and, where possible, the use of antioxidant drugs may reduce the toxic metabolites responsible for tissue damage.

Simultaneously with the events described with surgical trauma and elevation of the flap, an inflammatory process mediated by kinins, serotonin and histamine occurs, resulting in increased microcirculation permeability, with tissue edema, which impairs perfusion and contributes to decrease vascularization in the distal segment of the flap ${ }^{7}$. Post-trauma tissue edema may last from four to 24 hours $^{8-10}$. Partial or total skin flap necrosis may require other surgical in terventions, which is a challenging situation for the surgeon

Several experimental studies have used drugs to attenuate the formation of reactive oxygen species and tissue edema, and to stimulate tissue repair ${ }^{7}$, such as hyaluronidase ${ }^{8}$, dimethylsulfoxide ${ }^{9,11-13}$, sildenafil ${ }^{10}$, pentoxifylline ${ }^{6,14-16}$, streptokinase and allopurinol17, L-arginine $^{18}$, Kaurenoic acid ${ }^{19}$ and latex sap of Hevea brasiliensi20. Dimethylsulfoxide has an analgesic and anti-inflammatory effect, acts on coagulation, mainly in the cascade of arachidonic acid, is an inhibitor of platelet aggregation and acts as a subdermal vasodilator, antioxidant, free radical scavenger, protecting from the ischemia-reperfusion phenomenon $2,5,9,11-13,19$ Pentoxifylline has hemorheological properties, increases erythrocyte deformability and acts on the coagulation cascade, with thromboxane release and increased prostacyclin synthesis. As an important vasodilator, it acts on the morphological and biochemical immunomodulation mechanism and contributes to decrease reactive oxygen species ${ }^{4,6,14-16,19}$.

The present study aims to evaluate the effects of dimethylsulfoxide (DMSO) and pentoxifylline (PTFL) on the vitality of skin flaps in rats.

\section{METHODS}

We studied 30 male, non-isogenic Wistar rats (Rattus norvegicus, Rodentia Mammalia), with a mean age of three months and a mean weight of 302 grams, acquired by the Reproduction Biology Center (CBR) of the Federal University of Juiz de Fora - MG (UFJF-MG). We followed the ethical principles in animal experimentation according to the Brazilian College of Animal Experimentation (COBEA). All protocols and procedures are in accordance with Federal Law No. 11.734 of $10 / 08 / 2008^{21-23}$ and the project was approved by the Ethics in Research Committee of the Federal University of Minas Gerais, according to protocol 251/2013.

We divided the sample into three groups, distributed as follows: Control group $(n=10)$ : gauze moistened with $0.9 \%$ saline solution in the flap bed for 30 seconds; DMSO group $(n=10)$ : injection of $1 \mathrm{ml}$ of $5 \%$ dimethylsulfoxide divided into five injections of $0.2 \mathrm{ml}$ in the transition of the flap segments; PTFL group ( $n=10)$ : injection of pentoxifylline $20 \mathrm{mg} / \mathrm{kg}$, diluted with bidistilled water to complete the volume of $1 \mathrm{ml}$ and divided into five injections of $0.2 \mathrm{ml}$ in the transition of the flap segments.

We anesthetized the animals with $90 \mathrm{mg} / \mathrm{kg}$ of $5 \%$ ketamine hydrochloride, associated with $10 \mathrm{mg} /$ $\mathrm{kg}$ of $2 \%$ xylazine intraperitoneally 20 . We marked the flap on the back of the animals with a blue pilot overhead and a millimeter ruler, of $2 \mathrm{~cm} \times 8 \mathrm{~cm}$ (16 $\left.\mathrm{cm}^{2}\right)$, according to the McFarlane's rectangular flap, with caudal base vascular supply ${ }^{3,8,11}$. We divided the flaps in every $2.6 \mathrm{~cm}$ into proximal, intermediate and distal segments, and performed flap dissection up to the fleshy pannicus, including it. We submitted all the animals to the procedure with the same technique and, after elevation of the flap, we administered the drugs. We intraoperatively injected the flap borders in a single, subcutaneous dose, with 1-ml syringe, 3-mm needle, as follows: two injections of $0.2 \mathrm{ml}$ on the right side and two injections on the left side, at the transition of the proximal and intermediate segment and at the transition of the intermediate and distal segment, and one injection of $0.2 \mathrm{ml}$ at the center of the distal segment (Figure 1). Then, we repositioned the flap in the bed and sutured it with single, separated stitches of 4.0 monofilament nylon, $0.5 \mathrm{~cm}$ distant from each other. We used no antibiotic and made no dressings.

We observed the animals daily, evaluating the behavior, weight and aspect of the flap. We measured the total and viable tissue lengths with the anes- 
thetized animal prior to the procedure. Total size and necrotic tissue size were measured with the anesthetized animal on the day of euthanasia. The same observer performed all the measurements, with a millimeter ruler. We considered a macroscopic aspect of viable tissue to be one with normal coloration and texture or with few changes in the superficial skin layer, and necrosis, when the skin had a hard texture, dark color and crust $^{24}$.

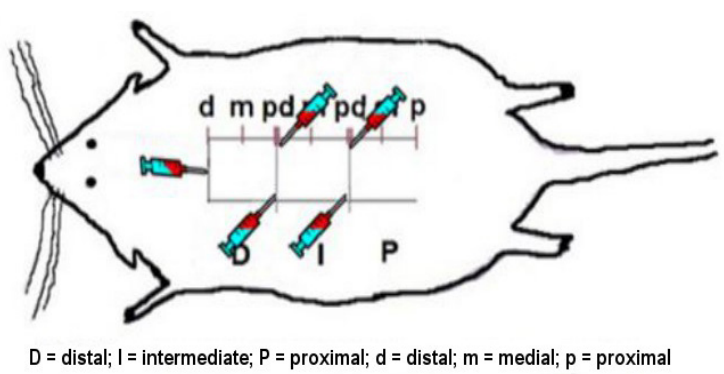

Figure 1. Drug Administration Scheme.

On the 10th postoperative day, we euthanized the animals under anesthesia with $180 \mathrm{mg} / \mathrm{kg} 5 \%$ ketamine and $20 \mathrm{mg} / \mathrm{kg} 2 \%$ xylazine ${ }^{23}$. We resected the flap specimen, which was adhered in a filter paper mold and placed in 10\% neutral buffered formaldehyde solution for 48 hours for fixation. The specimen was duly identified and sent for histological analysis, which was performed in 4- $\mu$ m thickness sections stained with hematoxylin and eosin. The steps were carried out at the Pathology Laboratory of the Holy Home of Mercy of Juiz de Fora, MG, and in the Department of Morphology of the Biological Sciences Institute of the Federal University of Juiz de Fora, MG, by an observer unknown to the group of the sample studied. An Olympus BX 51 microscope was used. The histological study of the flap was done in order to evaluate the evolution of the tissue repair process and the effect of dimethylsulfoxide and pentoxifylline on their vitality $7,10,25,26$. In the qualitative analysis of each sample of proximal, intermediate and distal segment, we observed the epidermis, layers of the dermis and the layers of the fleshy paniculus. The presence of neoformed vessels and leukocyte inflammatory infiltrate was considered granulation, and necrosis was the presence of devitalised elements.
The categorical variables were: granulation, granulation with leukocytes, granulation and/or necrosis, analyzed in the central portion of the proximal, intermediate and distal segments, respectively ${ }^{10,25,26}$. We divided the variables into six categories, assigning the respective scores and descriptions of each, according to the histological findings: a) ABSENT (score $=0$ ) - absence of vessels and cellular elements of granulation; b) DISCRETE (score= 1) - granulation with few vessels, collagen fibers and sparse leucocytes in the optical field; c) MODERATE (score= 2) - granulation with greater frequency of dispersed vessels in the field and of collagen fibers, and leukocytes forming aggregates, with areas free of infiltration; d) INTENSE (score= 3 ) - granulation with vessels arranged in the whole field, collagen fibers and leucocytes with dense aggregate, without areas free of infiltrate; e) INTENSE + NECROSIS (score $=4)$ - granulation with vessels arranged throughout the field, collagen fibers and leukocytes forming a dense aggregate, without an area free of infiltrate, with areas of necrosis, intercalated or close to the granulation tissue, called granulation and necrosis foci; f) NECROSIS (score $=5$ ) - fields full of devitalized elements, frequently evidenced, called necrosis.

The image capture of the slides was performed at the Genetics Laboratory of UFJF-MG, with the Cybernetics $®$ Image-Pro Plus 4.5 software, coupled to the Olympus BX 51 microscope, in 25x, 40x and 100x magnifications. The photographic documentation of the animals was performed in all stages of the experiment on the same days, D1, D3, D5, D7 and D10, in all groups, by the same observer, with a professional digital camera Cannon EF 100 mm, 1:2:8 USM - Tokyo - Japan.

We calculated the sample size with significance level between 0.01 and 0.05 , coefficient of variation of 15 to $20 \%$ for differences between the treated and control groups ${ }^{17}$. We performed the statistical study of the variables of the three groups with the software Statistical Package for Social Sciences (SPSS) ${ }^{18}$, and analyzed the categorical variables of the histological analysis with the software R Core version 3.0.1 (2013: 05.16), both with the contribution of the Biostatistical Support Nucleus of the Faculty of Medicine of UFMG. We analyzed the pairs of means different from the categorical 
variables studied with the ANOVA and Fisher's exact tests. The associations between the control, DMSO and PTFL groups were interpreted and clarified. The adjusted residue was equal to or greater than 1.96, when there was a significant association between the group variable and the category and $p$ value $<0.05$.

\section{RESULTS}

Four animals died in the immediate postoperative period, three in the PTFL group and one in the control group. On the 10th postoperative day, one animal of the DMSO group had clear fluid and trabeculae in the flap bed, suggestive of infection. We replaced these five animals. At clinical observation until the 10th day, the animals in the experiment showed no signs of suffering, such as bent posture, behavioral changes, ocular or nasal secretion, hair bruising and diarrhea. They accepted food and water routinely. The aspect of the cutaneous flap varied from pallor, cyanosis to necrosis. The texture in the distal segment was gradually modified in all groups, becoming hardened, with crusts, with subtle differences between the DMSO and PTFL groups. We observed the delimitation of tissue necrosis on the seventh postoperative day. We submitted the measurements of the total flap size, viable tissue size and necrotic tissue size of each animal, as well as the equivalent percentages among the three groups, to the ANOVA test, which did not significant differences, with ( $p>0.05$ - Table 1).

Table 1. Means and standard deviations (SD) of the flap dimensions and p-value.

\begin{tabular}{lcccc}
\hline \multicolumn{1}{c}{ Dimension of the skin flap } & $\begin{array}{c}\text { Control } \\
\text { Mean (SD) }\end{array}$ & $\begin{array}{c}\text { DMSO } \\
\text { Mean (SD) }\end{array}$ & $\begin{array}{c}\text { PTFL } \\
\text { Mean (SD) }\end{array}$ & $p$ \\
\hline Overall dimension $(\mathrm{cm})$ & $7.16( \pm 0.00)$ & $(6.98 \pm 0.36)$ & $6.87( \pm 0.30)$ & 0.240 \\
Viable tissue $(\mathrm{cm})$ & $3.81( \pm 0.53)$ & $3.85( \pm 0.75)$ & $(3.69 \pm 0.51)$ & 0.831 \\
Necrotic tissue $(\mathrm{cm})$ & $3.35( \pm 0.47)$ & $(3.13 \pm 0.63)$ & $3.18( \pm 0.47)$ & 0.630 \\
Viable tissue $(\%)$ & $53.17( \pm 6.40)$ & $53.98( \pm 10.03)$ & $53.69( \pm 6.87)$ & 0.973 \\
Necrotic tissue $(\%)$ & $46.37( \pm 6.40)$ & $45.37( \pm 9.24)$ & $45.41( \pm 6.96)$ & 0.888 \\
\hline
\end{tabular}

The frequency in absolute numbers of the variables granulation and granulation/leukocytes in the proximal and intermediate segments was not significant ( $p>0.05$. The control group presented the variable granulation/necrosis, with three cases of intense granulation (score $=3$ ), one with intense granulation and necrotic foci $($ score $=4)$ and six with necrosis alone $($ score $=5)$. The DMSO group presented, in the variable granulation/necrosis, three cases of intense granulation $($ score $=3)$ and seven with intense granulation and necrotic foci (score= 4). The PTFL group presented, in the variable granulation/ necrosis, three cases with moderate granulation (score= $2)$, five with intense granulation (score $=3$ ) and only two with intense granulation with necrotic foci $($ score $=4)$. The frequency in absolute numbers of the variable granulation/necrosis in the distal segment in the control, DMSO and PTFL groups were significant $(p=0.0004791)$. No spe- cimen from the DMSO or PTFL groups displayed necrosis (score $=5$ ) when compared with the control group, which had six cases of necrosis $(p=0.0004791)$. These results suggest effects of the drugs on tissue repair (Table 2).

Figure 2 shows photomicrographs of the histological section of the distal segment of the control group, where there is inflammatory infiltrate and predominance of vacuoles, edema and necrosis. Figure 3 shows a histological section photomicrograph of the distal segment of the DMSO group with elements with intense inflammatory infiltrate with necrotic foci and neovascularization, structured connective tissue stroma. Figure 4 depicts a histological section photomicrograph of the distal segment of a PTFL group specimen, showing moderate inflammatory infiltrate, neovascularization and absence of necrosis. All specimens were analyzed with a 100x magnification and hematoxylin and eosin staining. 
Table 2. Scores assigned in histological evaluation.

\begin{tabular}{cccccc}
\hline Variable/Group & Score (category) & Control & DMSO & PTFL & $p$ \\
\hline Granulation & Absent (0) & 5 & 9 & 5 & 0.124 \\
& Discreet & 5 & 1 & 5 & \\
\hline $\begin{array}{c}\text { Granulation/ } \\
\text { Leukocytes }\end{array}$ & Discrete (1) & 5 & 7 & 5 & 0.643 \\
& Moderate (2) & 5 & 3 & 1 & $3 *$ \\
Intense (3) & 0 & 0 & $5 *$ & \\
Moderate (2) & 0 & 0 & 3 & 2 & 0.0004791 \\
Intense (3) & 3 & $7 *$ * & 0 & \\
\hline
\end{tabular}

* statistical significance

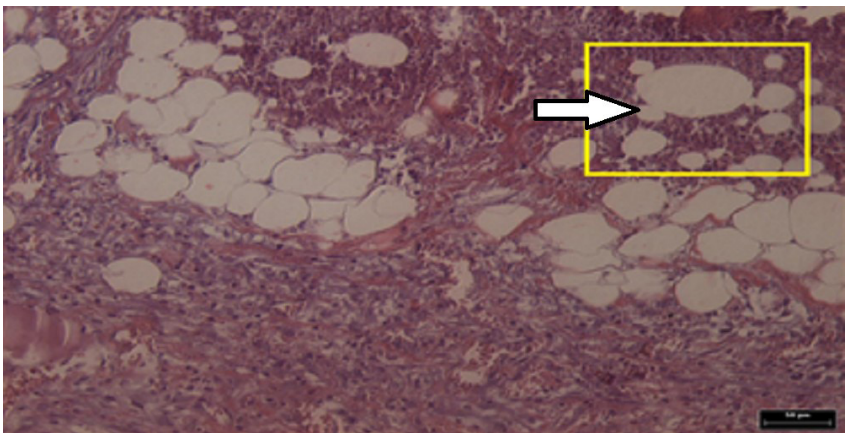

Figure 2. Photomicrography of control group specimen: (i) inflammatory infiltrate, edema, necrosis, HE-100x.

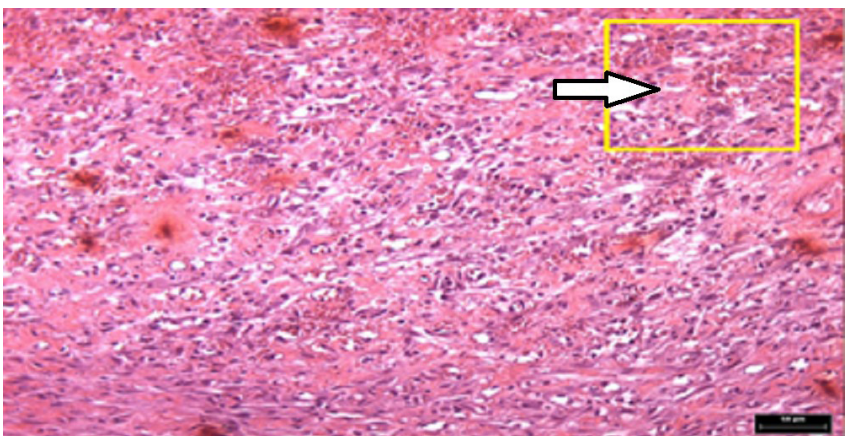

Figure 3. Photomicrography of DMSO group specimen: neoformed vessels, inflammatory infiltrate, H.E-100x.

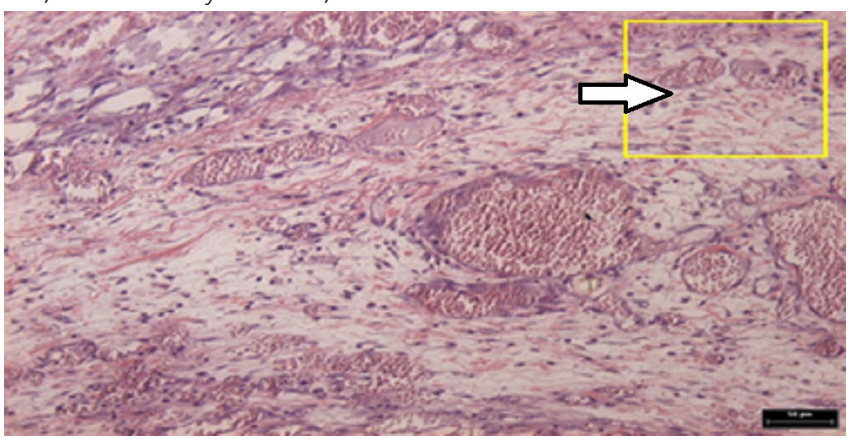

Figure 4. Photomicrography of PTFL group specimen: neoformed vessels, inflammatory infiltrate, H.E-100x.

\section{DISCUSSION}

The choice of the rat for the experiment in this research was due to the ease of animal acquisition, simple handling, low cost and feasible conditions for research. Moreover, this animal is widely used as a model in research $1,4,8,9,11,14,16$. The McFarlane skin flap was standardized with a caudal base vascular supply and we created a difficult condition of venous return, favoring tissue edema, increased capillary pressure and consequent increase in necrosis, thus allowing investigation of the influence of the possible effects of DMSO and PTFL on tissue repair and on the vitality of the flap in face of such conditions $3,8,11,24,27-29$.

Studies indicate that the tissue dimensions with cutaneous necrosis get delimited on the seventh postoperative day ${ }^{24}$. In the present work we decided to maintain the clinical observation of the animals for ten days, considering that Almeida et al. ${ }^{9}$, in 2004, reported that the period required for the reorganization of the vascular supply of the flap was nine days.

Drug administration was performed with a 3-mm needle to reduce local trauma, and the volume of $1 \mathrm{ml}$, not to cause edema and to avoid the reduction of perfusion. We chose the subcutaneous route because of the better dispersion of the substance, since it is easily accessible, capable of obtaining an adequate level of concentration in the tissues adjacent to the flap, with little systemic absorption, thus increasing admi- 
nistration safety 9 . We did not find in the literature a study with PTFL administration, but only the Almeida9 study, with subcutaneous DMSO.

The reperfusion of the ischemic area can lead to the formation of reactive oxygen species that cause tissue damage and culminate with necrosis ${ }^{4}$. Oxidative stress, a result of this process, starts from the first minutes after trauma and can be one of the factors responsible for cell death, with tissue loss, mainly in the flap's distal segment. We believe that surgical trauma, such as the flap confection, causes an endogenous imbalance in the formation of reactive oxygen species from the first postoperative minutes. We rely on the premise that oxidative stress occurs early in the surgical trauma, and has repercussions throughout the flap healing, which is why we decided to perform the injections of drugs intraoperatively in a single dose $\mathrm{e}^{1,2,4,9,10}$. In previous research, it was found that antioxidant substances ${ }^{21}$, as well as DMSO and PTFL, can act favorably and early in the operative wound ${ }^{1,4,5,6,9,11-16,19}$.

The intermediate segments of the flap are those called the "transition zone", since they are between the proximal portion, where the survival of the flaps is expected due to the proximity of the vascular supply, and the distal portion, where necrosis can occur due to the distance from the blood supply. These areas submitted to a period of ischemia and subsequent reperfusion are those in which the pharmacological intervention can modify the flap's evolution. The purpose is to improve the vitality of the flap through the vasodilation in the microcirculation and increase the perfusion pressure with consequent benefit to the tissues $^{10}$. Since DMSO and PTFL have antioxidant properties, the research proposal was to administer them subcutaneously and to evaluate the effects on the flap's tissue repair. We observed histological features of granulation, such as exuberant neovascularization, inflammatory infiltrate with leukocytes in the PTFL group, and more structured conjunctival stroma with neovascularization in the DMSO group, in addition to the absence of necrotic specimens in the group treated with PTFL ${ }^{25,26}$. We observed necrosis in $60 \%$ of the specimens in the distal segment of the control group animals.

This research envisaged a horizon for the use of DMSO and PTFL to expand effective strategies to improve the vitality of cutaneous flaps, reducing or even avoiding necrosis. These drugs are affordable and available for therapeutic use in skin flaps. It is necessary to dedicate new researches to promoting knowledge about the safety and the tissue modifications under the influence of these drugs and, thus, to extrapolate their use for medical practice.

Our study demonstrated that DMSO and PTFL influenced the vitality of the skin flap and the tissue repair process in rats. The animals treated with these drugs had neovascularization and infiltrate with leukocytes statistically superior to those observed in the control group animals, which expressed devitalized tissues. However, they did not prevent macroscopic necrosis.

\section{R E S U M O}

Objetivos: verificar a influência do dimetilsulfóxido e da pentoxifilina na vitalidade e no processo de reparo tecidual de retalhos cutâneos em ratos. Método: foram estudados 30 ratos Wistar, nos quais foi confeccionado retalho cutâneo dorsal de $2 \mathrm{~cm}$ de largura por $8 \mathrm{~cm}$ de comprimento, de base caudal, e distribuídos em três grupos: Grupo Controle $(n=10)$ com aplicação de gaze umedecida com solução salina a 0,9\%, no leito do retalho, por 30 segundos; Grupo dimetilsulfóxido $(n=10)$ com injeção de $1 \mathrm{ml}$ de dimetilsulfóxido a $5 \%$ divididos em cinco injeções de $0,2 \mathrm{ml}$ na transição dos segmentos do retalho; Grupo pentoxifilina $(\mathrm{n}=10)$ com injeção de $1 \mathrm{ml}$ pentoxifilina $20 \mathrm{mg} / \mathrm{kg}$, divididos em cinco injeções de $0,2 \mathrm{ml}$ na transição dos segmentos do retalho. Os fármacos foram administrados no transoperatório, em dose única e por via subcutânea. Os retalhos cutâneos foram observados quanto às alterações de cor e textura. No décimo dia de pós-operatório aferiu-se a dimensão do tecido viável e de necrose, seguido da exérese da peça para análise histológica. Resultados: a medida da dimensão de tecido viável e de necrose dos grupos não apresentou diferenças. A análise histológica mostrou que o grupo dimetilsulfóxido apresentou neovascularização, infiltrado inflamatório com leucócitos e estroma conjuntivo mais estruturado. O grupo pentoxifilina, mostrou neovascularização e infiltrado inflamatório com granulação moderada e intensa. O grupo controle evoluiu com maior índice de necrose no segmento distal. Conclusão: dimetilsulfóxido e pentoxifilina influenciaram na vitalidade do retalho e no processo de reparo tecidual. Entretanto, não evitaram a necrose macroscopicamente.

Descritores: Cicatrização. Dimetil Sulfóxido. Pentoxifilina. Ratos. Retalhos Cirúrgicos. 


\section{REFERENCES}

1. Cymrot M, Percário S, Ferreira LM. Comportamento do estresse oxidativo e da capacidade antioxidante total em ratos submetidos a retalhos cutâneos isquêmicos. Acta Cir Bras. 2004;19(1):18-26.

2. Barreiros ALBS, David JM, David JP. Estresse oxidativo: relação entre geração de espécies reativas e defesa do organismo. Quím Nova. 2006;29(1):113-23.

3. Camargo CP, Margarido NF, Guandelini E, Vieira $\mathrm{GA}$, Jacomo AL, Gemperli R. Description of a new experimental model skin flap for studying skin viability in rats. Acta Cir Bras. 2014;29(3):166-70.

4. Campos EBP, Yoshida WB. O papel dos radicais livres na fisiopatologia da isquemia e reperfusão em retalhos cutâneos: modelos experimentais e estratégias de tratamento. J Vasc Br. 2004;3(4):357-66.

5. Guimarães SB, Kimura OS, Vasconcelos PRL. Dimetilsulfóxido atenua a lesão de isquemia-reperfusão em testículo de ratos. Acta Cir Bras. 2010:25(4):35761.

6. Hybertson BM, Gao B, Bose SK, McCord JM. Oxidative stress in health and disease: the therapeutic potential of Nrf2 activation. Mol Aspects Med. 2011;32(46):234-46.

7. Balbino CA, Pereira LM, Curi R. Mecanismos envolvidos na cicatrização: uma revisão. Rev Bras Cienc Farm. 2005;41(1):27-51

8. Acevedo-Bogado CE, Bins-Ely J, D'Acampora AJ, Neves RE. Efeito da hialuronidase na sobrevida de retalhos cutâneos em ratas. Acta Cir Bras. 2002;17(Suppl. 1):14-6.

9. Almeida KG, Fagundes DJ, Manna MCB, Montero EFS. Ação do dimetil-sulfóxido na isquemia de retalhos randômicos de pele em ratos. Acta Cir Bras. 2004;19(6):649-57.

10. Barral SM, Araújo ID, Vidigal PV, Mayrink CA, Araujo $A D$, Costa PR. Effects of sildenafil on the viability of random skin flaps. Acta Cir Bras. 2011; 26(4):314-9.

11. Adamson JE, Horton CE, Crawford HH, Ayers WT Jr. The effects of dimethyl sulfoxide on the experimental pedicle flap: a preliminary report. Plast Reconstr Surg. 1966;37(2):105-10

12. Celen O, Yildirim E, Berberoglu U. Prevention of wound edge necrosis by local application of dimethylsulfoxide.
Acta Chir Belg. 2005;105(3):287-90.

13. Melo JUDS, Vasconcelos PRLD, Santos JMV, Campos Júnior MM, Barreto MVA, Kimura ODS. Efeitos do dimetilsulfóxido no estresse oxidativo e na regeneração hepática pós-hepatectomia em ratos. Rev Col Bras Cir. 2008;35(2):103-8.

14. Babaei S, Bayat M, Nouruzian M, Bayat M. Pentoxifylline improves cutaneous wound healing in streptozotocininduced diabetic rats. Eur J Pharmacol. 2013;700(13):165-72

15. Brasileiro JL, Fagundes DJ, Miiji LON, Oshima CTF, Teruya R, Marks G, et al. Isquemia e reperfusão de músculo sóleo de ratos sob ação da pentoxifilina. J Vasc Bras. 2007;6(1):50-63.

16. Leal PR, Cammarota MC, Sbalchiero J, Marques MM, Moreira M. Efeitos da pentoxifilina e o cloridrato de buflomedil em retalhos randomizados em ratos sob influência da nicotina. Rev Soc Bras Cir Plast. 2004;19(3):31-42.

17. Moura T, Marques AA, Bernal SO, Gagliocca GD, Gemperli R, Ferreira MC. Estudo da ação da estreptoquinase e do alopurinol em retalhos cutâneos em ilha submetidos à isquemia prolongada: estudo experimental em ratos. Rev Assoc Med Bras. 2009;55(5):601-5.

18. Guimarães MVTN, Moreira GHG, Rocha LP, Nicoluzzi JEL, Souza CJF, Repka JCD. Ação da I-arginina na evolução de retalhos cutâneos de ratos sob exposição à nicotina. Rev Col Bras Cir. 2013;40(1):49-54.

19. Silva JJ, Pompeu DG, Ximenes NC, Duarte AS, Gramosa NV, Carvalho KM, et al. Effects of kaurenoic acid and arginine on random skin flap oxidative stress, inflammation, and cytokines in rats. Aesthetic Plast Surg. 2015;39(6):971-7.

20. Penhavel MVC, Tavares VH, Carneiro FP, Sousa JBD. Effect of Hevea brasiliensis latex sap gel on healing of acute skin wounds induced on the back of rats. Rev Col Bras Cir. 2016;43(1):48-53.

21. Eckelman WC, Kilbourn MR, Joyal JL, Labiris R, Valliant JF. Justifying the number of animals for each experiment. Nucl Med Biol. 2007;34(3):229-32.

22. Damy SB, Camargo RS, Chammas R, Figueiredo LFPD. Aspectos fundamentais da experimentação animal: aplicações em cirurgia experimental. Rev Assoc Med Bras. 2010;56(1):103-11. 
23. Universidade Federal de Minas Gerais. Comitê de Ética em Experimentação Animal. Protocolos anestésicos comumente utilizados em animais de pequeno porte. Belo Horizonte: CETEA-UFMG; 2012.

24. Pace D, Campos AC, Graf R. Efeito de substâncias antioxidantes (vitamina $C$, vitamina $E$ e gingko biloba) na viabilidade de retalho cutâneo dorsal em ratos. Rev Soc Bras Cir Plast. 2006;21(2):77-81.

25. Garros IC, Campos ACL, Tâmbara EM, Tenório SB, Torres OJM, Agulham MA, et al. Extrato de Passiflora edulis na cicatrização de feridas cutâneas abertas em ratos: estudo morfológico e histológico. Acta Cir Bras. 2006;21(Supll. 3):55-65.

26. Martins NLP, Malafaia O, Ribas-Filho JM, Heibel M, Baldez RN, Vasconcelos PRL, et al. Análise comparativa da cicatrização da pele com o uso intraperitoneal de extrato aquoso de Orbignya phalerata (babaçu). Estudo controlado em ratos. Acta Cir Bras. 2006;21(Suppl 3):66-75.

27. Costa W, Silva AL, Costa GR, Nunes TA. Histology of the rectus abdominis muscle in rats subjected to cranial and caudal devascularization. Acta Cir Bras. 2012;27(2):162-7.

28. Ohara H, Kishi K, Nakajima T. Rat dorsal paired island skin flaps: a precise model for flap survival evaluation. Keio J Med. 2008:57(4):211-6.

29. Kelly CP, Gupta A, Keskin M, Jackson IT. A new design of a dorsal flap in the rat to study skin necrosis and its prevention. J Plast Reconstr Aesthet Surg. 2010;63(9):1553-6.

Received in: 06/04/2017

Accepted for publication: 25/05/2017

Conflict of interest: none.

Source of funding: none.

\section{Mailing address:}

Stephanie Luzia da Costa Pedretti

E-mail: stephanielcpedretti@yahoo.com.br / tan@medicina.ufmg.br 